\title{
Validitas preparat histologi sebagai media pembelajaran submateri pencemaran air
}

\section{Ruqiah Ganda Putri Panjaitan*, Eko Sri Wahyuni, Mutmainnah}

Pendidikan Biologi, Universitas Tanjungpura, Jl. J.A. Yani, Pontianak (78I24), KAL-BAR, Indonesia

*Korespondensi penulis: ruqiah.gpp@fkip.untan.ac.id

\begin{tabular}{|c|c|}
\hline Informasi & Irtikel \\
\hline Riwayat a & tikel: \\
\hline Dikirim & OI Desember 2019 \\
\hline Direvisi & 22 Januari 2020 \\
\hline Diterima & I8 Februari 2020 \\
\hline Dipublika & i 07 April 2020 \\
\hline
\end{tabular}

\section{Kata kunci:}

Media pembelajaran, preparat histologi, pencemaran air
Penelitian ini bertujuan untuk mengetahui validitas preparat histologi sebagai media pembelajaran pada submateri pencemaran air kelas X SMA. Metode penelitian yang digunakan adalah metode deskriptif dengan bentuk penelitian kuantitatif. Penelitian ini terdiri dari dua tahapan yakni tahapan pembuatan preparat dan validasi media. Validasi media preparat dilakukan oleh validator, dan instrumen penilaian berupa kuesioner yang terdiri dari aspek tampilan media preparat, ketepatan materi, dan mikroteknik. Hasil validasi menunjukkan nilai rata-rata total validasi untuk preparat I.I sebesar 3,83; preparat I.2 sebesar 3,83; preparat 2.I sebesar 3,8I; preparat 2.2 sebesar 3,83; preparat 3.I sebesar 3,85; dan preparat 3.2 sebesar 3,85 . Dapat disimpulkan bahwa preparat histologi valid digunakan sebagai media pembelajaran pada submateri pencemaran air.
Keywords:

Instructional media, microscope slides, water pollution

\section{ABSTRACT}

The validity of microscope slides on sub-materi water pollution as learning media. This research aims to evaluate the validity of microscope slides as learning media on sub-materi water pollution. The research method used is descriptive method with the form of quantitative research. This research consists of two phases: creating and the validation of media microscope slides. Microscope slides media validation was performed by validator. The instrument of assessment is questionnaire which consisting of appearance of media, material accuracy, and microtechniques. The result showed total average of microscope slides I.I is 3.83; microscope slides I.2 is 3.83; microscope slides 2.1 is 3.8I; microscope slides 2.2 is 3.83; microscope slides 3.I is 3.85; and microscope slides 3.2 is 3.85. It is concluded the microscope slides microscope slides are valid as learning media on sub materi water pollution.

(C) 2020 Panjaitan et al This is an open access article under the CC-BY-SA license

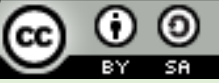

Sitasi: Panjaitan, R.Q.P., Wahyuni, E.S., \& Mutmainnah. (2020). Validitas preparat histologi sebagai media pembelajaran submateri pencemaran air. JPBIO (Jurnal Pendidikan Biologi), 5(I), 20-26. DOI: 10.31932/jpbio.v5iI.564

\section{PENDAHULUAN}

Pembelajaran adalah kegiatan utama yang terjadi di dalam kelas. Pembelajaran merupakan interaksi antara pendidik dan peserta didik yang melalui tahapan-tahapan dalam memperoleh pengetahuan, penguasaan kemahiran, pembentukan sikap, dan kepercayaan (Hanafy, 20I4). Pembelajaran merupakan proses komunikasi antara guru dan peserta didik atau antar peserta didik dengan tujuan untuk mencapai tujuan pembelajaran (Raehang, 20I4). Guru memiliki peran untuk mendorong, membimbing, dan memfasilitasi peserta didik (Matsun et al., 2019), dan salah satu fasilitas yang dapat diberikan guru adalah dengan menyajikan informasi atau pesan dalam proses pembelajaran dengan bantuan media pembelajaran (Enawaty \& Sari, 2010). 
Media pembelajaran adalah sarana penyalur pesan atau informasi (Nurseto, 20II). Media pembelajaran merupakan alat bantu untuk memudahkan peserta didik dalam memahami materi ( Panjaitan et al., 2016; Deadara et al., 2017; Desriana et al., 2018; Panjaitan et al., 2019a; Panjaitan et al., 2019b; Panjaitan et al., 2019 c, Pradilasari et al., 2019), meningkatkan efisiensi dan efektivitas pengajaran (Baharuddin, 2015), meningkatkan kemandirian peserta didik (Pramana et al., 2014), serta meningkatkan kemampuan berpikir kritis (Heni et al., 2017; Wahyuni et al., 2018). Tidak hanya itu, melalui pemebelajaran berbantuan media peserta didik juga diharapkan dapat menggunakan alat inderanya untuk mengamati, mendengar, merasakan, meresapi, menghayati, sehingga dengan demikian peserta didik diharapkan akan memiliki pengetahuan, sikap, dan keterampilan (Umar, 2013), sekaligus dapat membangun karakter peserta didik (Titin et al., 2018).

Salah satu materi biologi di kelas $\mathrm{X}$ adalah perubahan lingkungan atau iklim dan daur ulang limbah. Berdasarkan silabus biologi Kurikulum 2013, kompetensi dasar 3.10 untuk materi ini adalah menganalisis data perubahan lingkungan dan dampak dari perubahan-perubahan tersebut bagi kehidupan. Hasil wawancara dengan guru biologi menunjukkan bahwa metode yang biasa digunakan pada submateri pencemaran air adalah metode eksperimen berupa uji toksisitas. Uji toksisitas yang biasanya dilaksanakan di sekolah dengan menggunakan ikan, deterjen, dan air. Percobaan ini menggunakan ikan dan akan dimasukkan ke dalam air yang telah bercampur dengan deterjen atau air yang tercemar deterjen. Hasil percobaan yang dilakukan peserta didik tersebut menunjukkan bahwa ikan akan mengalami kesulitan bernafas bahkan mati jika diletakkan di dalam air yang tercemar deterjen. Namun, dari hasil percobaan ini tentu saja belum dapat menggambarkan apa yang sesungguhnya terjadi di dalam jaringan penyusun tubuh ikan.

Peraturan Pemerintah (PP) No. 82 tahun (200I) dinyatakan bahwa pencemaran air adalah masuknya atau dimasukkannya makhluk hidup, zat, energi, dan atau komponen lain ke dalam air oleh kegiatan manusia, sehinga kualitas air turun sampai ke tingkat tertentu yang menyebabkan air tidak dapat berfungsi sesuai dengan peruntukannya. Sejalan dengan itu, Puspitasari (2009) menyatakan bahwa pencemaran akan menganggu lingkungan abiotik, biotik, dan lingkungan sosial, sehingga banyak hewan yang menjadi rusak atau mati karena pencemaran tersebut. Salah satu lokasi yang menunjukkan terjadinya pencemaran air dapat dilihat di Sungai Kapuas yang terletak di Desa Nanga Sepauk.

Sungai kapuas memiliki sumber daya berupa emas dan ikan, namun potensi emas di kawasan tersebut menjadi daya tarik untuk melakukan penambangan emas ilegal atau penambangan emas tanpa izin (PETI) yang mengakibatkan terjadinya pencemaran air. Selain PETI, pencemaran juga terjadi akibat sampah, limbah rumah tangga, dan aktivitas mandi cuci kakus yang masih banyak dilakukan oleh masyarakat yang tinggal di pinggiran sungai. Namun pada kenyataannya, masyarakat tersebut masih memanfaatkan biota yang hidup di perairan. Bahkan tak jarang masyarakat menangkap dan mengonsumsi ikan dari sungai di perairan sekitar tempat tinggal mereka. Padahal, Triadayani et al. (2010) telah membuktikan bahwa terjadinya kerusakan lingkungan akibat paparan zat toksik akan berpengaruh terhadap struktur jaringan hati ikan. Hal inilah yang mendorong dilakukannya penelitian ini dengan tujuan mengukur validitas media preparat histologi hati ikan baung sebagai media pembelajaran pada submateri pencemaran air.

\section{METODE PENELITIAN}

\section{Rancangan Penelitian}

Penelitian ini menggunakan metode deskriptif dengan bentuk penelitian kuantitatif. Penelitian deskriptif merupakan penelitian yang bertujuan untuk menjelaskan atau mendeskripsikan suatu keadaan, peristiwa, objek, apakah orang atau segala sesuatu yang terkait dengan variabel yang bisa dijelaskan baik dengan angka maupun kata-kata (Setyosari, 2013). Deskripsi yang dimaksud meliputi hasil uji kevalidan dari media preparat histologi yang dibuat oleh peneliti.

\section{Instrumen Penelitian}

Instrumen yang digunakan berupa lembar validasi. Lembar validasi digunakan untuk mengetahui validitas media preparat histologi pada materi pencemaran air. Penetapan aspek dalam lembar validasi mengacu pada Abidin et al., (20I4) serta memperhatikan prinsip umum pembuatan preparat awetan dan kesesuaian gambaran histologinya dengan lingkup materi pembelajaran.

\section{Prosedur Penelitian}

Prosedur penelitian ini terdiri dari dua tahapan. Tahap pertama adalah tahapan pembuatan media preparat histologi. Langkah-langkah pembuatan media preparat histologi dimulai dengan pengambilan sampel ikan baung (Hemibagrus nemurus). Sample ikan diambil dari kawasan sungai Kapuas yang berada di Desa Nanga 
Sepauk, selanjutnya hati ikan dipisahkan lalu dibersihkan dengan larutan $\mathrm{NaCl}$ 0,9\% kemudian direndam dengan larutan formalin 10\%. Pembuatan preparat mengacu pada Kiernan (1990). Setelah pembuatan preparat selesai, tahapan selanjutnya melakukan validasi preparat sebagai media pembelajaran. Jumlah preparat yang divalidasi ada 6 preparat.Validasi dilakukan dengan 9 orang validator.

\section{Teknik Analisis Data}

Analisis data validasi media dikembangkan mengacu pada Yamasari (2010). Data hasil perhitungan validasi kemudian dicocokkan dengan rata-rata total dengan kriteria kevalidan, yaitu:

$3 \leq$ RTVTK $\leq 4=$ valid

$2 \leq$ RTVTK $<3=$ cukup valid

$\mathrm{I} \leq \mathrm{RTVTK}<2=$ tidak valid

\section{HASIL PENELITIAN}

Sebuah media yang dikembangkan untuk digunakan sebagai media pembelajaran semestinya terlebih dahulu dinilai validitasnya. Uji validitas ini antara lain bertujuan agar media tersebut diyakini sesuai dengan materi dan memudahkan peserta didik dalam memahami materi. Demikan pula dengan penelitian ini, preparat histologi hati ini diharapkan dapat menjadi media pembelajaran, dan hasil validasi yang dilakukan terhadap media preparat hati ikan baung disajikan pada Tabel 1.

Tabel I. Data validasi preparat awetan hati ikan baung sebagai media pembelajaran pada sub materi pencemaran air

\begin{tabular}{lccccc}
\hline \multirow{2}{*}{ Nama Preparat } & \multicolumn{3}{c}{ Aspek } & $\begin{array}{c}\text { Rata-rata } \\
\text { tiap aspek }\end{array}$ & Keterangan \\
\cline { 2 - 5 } & Tampilan media preparat & Ketepatan materi & Mikroteknik & Valid \\
\hline Preparat I.I & 3,89 & 3,78 & 3,83 & 3,83 & Valid \\
\hline Preparat I.2 & 3,89 & 3,78 & 3,83 & 3,83 & Valid \\
\hline Preparat 2.I & 3,83 & 3,78 & 3,83 & 3,81 & Valid \\
\hline Preparat 2.2 & 3,89 & 3,78 & 3,83 & 3,83 & Valid \\
\hline Preparat 3.I & 3,94 & 3,78 & 3,83 & 3,85 & Valid \\
\hline Preparat 3.2 & 3,94 & 3,78 & 3,83 & 3,85 & Valid \\
\hline $\begin{array}{l}\text { Rata-rata tiap } \\
\text { preparat }\end{array}$ & 3,90 & 3,78 & 3,83 & 3,83 & Valid \\
\hline
\end{tabular}

PEMBAHASAN

Penilaian validitas media preparat histologi ini sebagai media pembelajaran sub materi pencemaran air ditinjau dari tiga aspek yakni aspek tampilan media preparat, aspek ketepatan materi, dan aspek mikroteknik. Aspek tampilan media preparat terdiri dari 2 kriteria yaitu kriteria identitas dan kriteria kerapian dan kebersihan. Penilaian kriteria identitas meliputi informasi mengenai tipe sayatan, nama objek dalam bahasa Indonesia, dan nama objek dalam bahasa latin. Berkaitan dengan penilaian kriteria identitas perlu dipahami bersama bahwa dengan melewati serangkaian tahapan pembuatan preparat akan mengubah tampilan organ dari bentuk segarnya. Tidak hanya itu, gambaran histologi suatu organ pun berbeda dengan gambaran morfologi organ tersebut, dan keadaan ini tentunya membutuhkan keahlian tertentu dari seseorang untuk dapat mengidentifikasi nama organ dari sebuah preprat awetan. Itu sebabnya informasi berupa pemberian label yang berisi informasi nama objek dan nama latin dari spesies yang diambil organnya sangat diperlukan guna memberikan informasi kemungkinan adanya variasi antara gambaran histologi suatu organ dari spesies yang satu terhadap spesies lainnya (Gambar I).

Abidin et al., (2014) mengungkapkan bahwa identitas pada preparat digunakan untuk mengetahui informasi yang terdapat dalam preparat. Kriteria kedua, yaitu kerapian dan kebersihan media preparat. Pembuatan preparat awetan, kerapian mutlak diperhatikan terutama saat melekatkan objek di atas kaca objek, karena peletakan yang tidak rapi mengakibatkan sayatan objek terlipat, menggulung, atau bertumpuk, dan ini tentunya membuat pengamatan terhadap objek menjadi terganggu. Selain itu, pembuatan preparat awetan juga perlu diperhatikan kerapian saat melekatkan kaca penutup objek ke kaca tempat melekatnya objek. Ketidakrapian saat melekatkan kaca penutup dapat mengakibatkan objek menjadi tidak terlindung sempurna dan ini berakibat objek menjadi lebih cepat rusak dan mengakibatkan terganggunya pengamatan objek. Pembuatan preparat juga perlu diperhatikan kebersihan sehingga sisa-sisa pewarna dan pelekat kaca objek dapat diminimalisir (Gambar I).

Aspek ketepatan materi meliputi kesesuaian media dengan tujuan pembelajaran dalam mengakomodir ranah belajar. Tujuan pembelajaran dari sub materi pencemaran air yang ingin dicapai adalah melalui pengamatan doli0.3I932/jpbio.v5iI.564 Panjaitan et al 
preparat peserta didik dapat mendiskusikan akibat yang ditimbulkan dari pencemaran air. Sehubungan dengan preparat histologi sebagai media pembelajaran sub materi pencemaran air, hasil validasi menunjukkan bahwa media preparat mampu mengakomodir ketiga ranah belajar yaitu kognitif, psikomotorik, dan afektif (Gambar 2). Pada penelitian ini, ranah kognitif diperoleh peserta didik dengan mengolah informasi setelah mengamati preparat, ranah psikomotorik berhubungan dengan keterampilan peserta didik, dan ranah psikomotorik dapat dilihat pada keterampilan peserta didik dalam pengamatan preparat dengan menggunakan mikroskop. Kemampuan media preparat dalam mengakomodir ranah psikomotorik juga terdapat pada kategori mendeteksi, membedakan, dan mengidentifikasi. Kemampuan media preparat dalam mengakomodir ranah afektif dapat dilihat pada saat peserta didik melakukan pengamatan preparat, yang diamati adalah sikap peserta didik selama melakukan pengamatan, dalam hal ini peserta didik ikut serta dalam melakukan pengamatan. Sebagaimana yang disampaikan Pramana et al., (2014); Deadara et al., (2017); Paramita et al., (2018); Desriana et al., (2018); Riska et al., (2018); Rozalinda et al., (2018); Wahyuni et al., (2018); Zakia et al., (2019); Yendrita \& Syafitri (2019); Pradilasari et al., (2019) bahwa media harus disesuaikan dengan tujuan pembelajaran sehingga dapat menghasilkan pembelajaran yang efektif. Bahkan media yang melibatkan peserta didik secara langsung dalam penggunannya akan membuat pembelajarannya menjadi lebih bermakna.

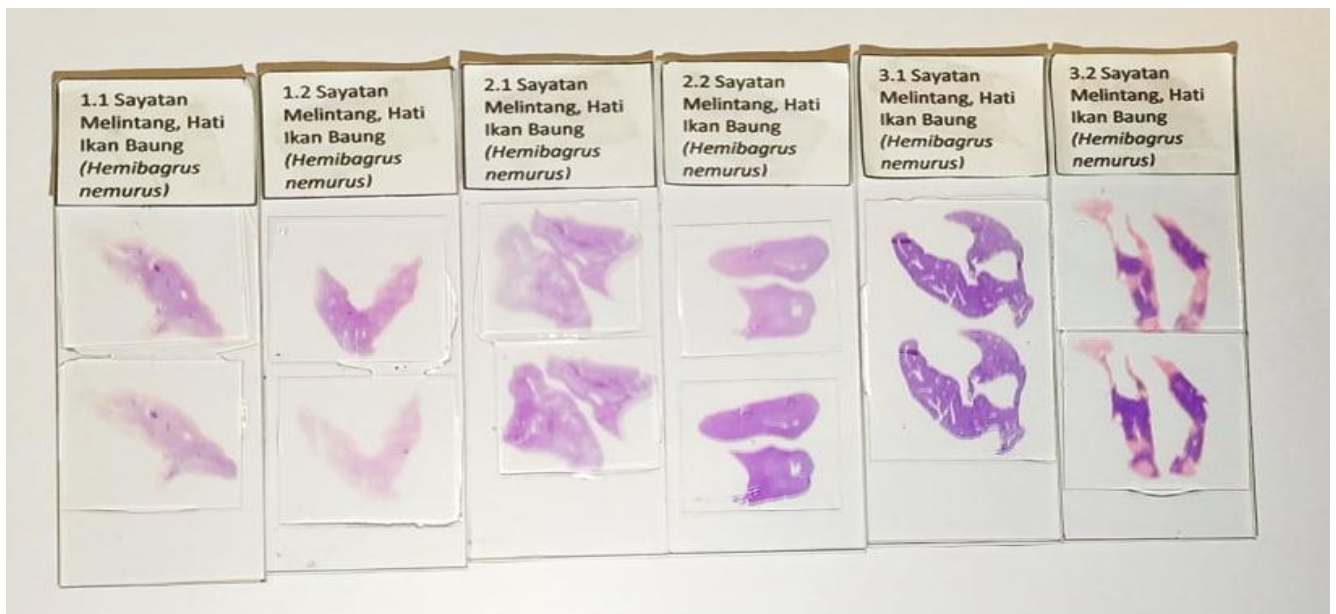

Gambar I. Tampilan media preparat

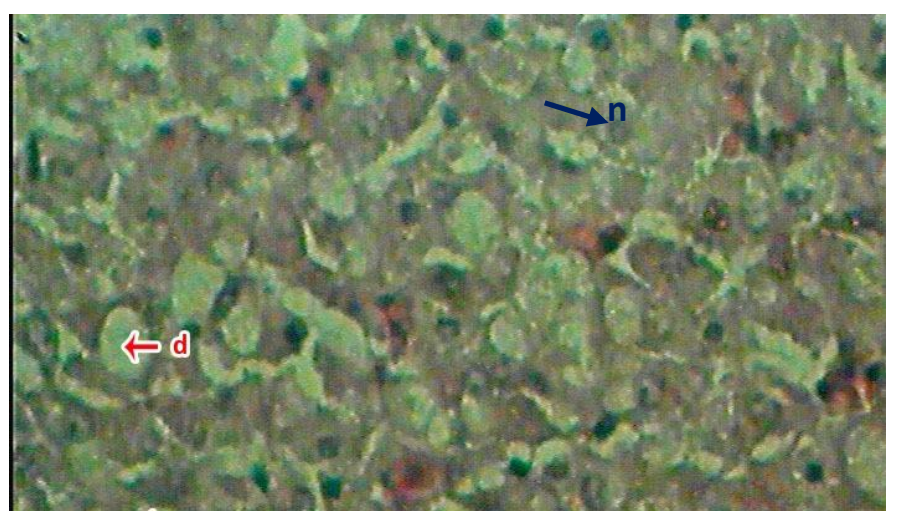

Gambar 2. Gambaran histologi hati ikan baung yang hidup di sungai Kapuas Desa Nanga Sepauk. Hasil pengamatan tanda panah merah menunjukkan sel hati mengalami degenerasi lemak (d) dan tanda panah biru menunjukkan sel hati normal (n) (Objektif 40x).

Media preparat ini diharapkan dapat digunakan dalam proses pembelajaran terutama untuk melihat dampak dari pencemaran air terhadap hati ikan. Hasil pengamatan histologi terhadap enam kaca objek menunjukkan bahwa hati ikan baung mengalami degenerasi lemak. Degenerasi sel adalah kelainan atau kerusakan sel yang diakibatkan cidera ringan yang bersifat reversible, artinya dapat diperbaiki apabila penyebab kerusakan sudah dihilangkan (Hestianah et al., 2010; Panjaitan et al., 2013). Menurut Panjaitan et al., (2013); Panjaitan (2017) degenerasi sel yang berlangsung lama akan menyebabkan terganggunya kelangsungan proses metabolisme yang mengakibatkan terjadinya kerusakan yang bersifat ireversibel bahkan terjadi kematian sel atau nekrosis sel. 
Adapun melalui penggunaan media preparat awetan histologi organ hati ikan baung ini diharapkan peserta didik dapat mengamati gambaran histologi hati ikan akibat air yang tercemar. Lebih lanjut, kedepannya akan menumbuhkan kesadaran di dalam diri peserta didik untuk menjaga kebersihan lingkungan terutama kebersihan sungai.

Aspek mikroteknik terdiri dari 2 kriteria yaitu pewarnaan dan ada tidaknya gelembung udara. Kiernan (1990) menyatakan tujuan pewarnaan dengan hematoksilin dan eosin adalah untuk dapat memperjelas struktur mikroskopis dari suatu sediaan. Pewarnaan dalam penelitian ini dapat memperjelas bagian inti sel hati dengan sitoplasma, serta memudahkan dalam pengamatan untuk melihat adanya perubahan antara lain terjadinya degenerasi (Gambar 3). Kriteria kedua ada tidaknya gelembung udara yang tampak pada preparat hati ikan baung.

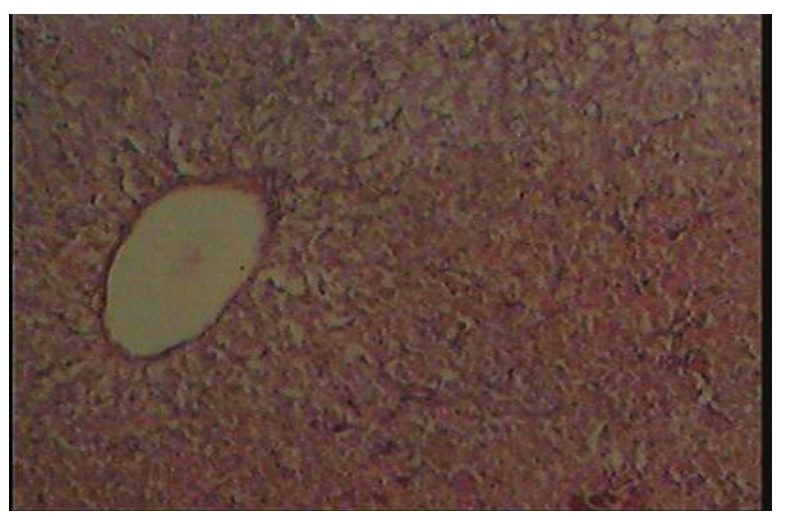

Gambar 3. Pewarnaan menggunakan hematoksilin eosin (HE) (Objektif IOx).

Adanya gelembung udara pada preparat histologi bermakna kurang baik, karena gelembung udara tersebut akan mengganggu pengamatan, namun pada preparat ini sendiri tidak ditemukan adanya gelembung udara (Gambar 3). Sebagaimana yang dinyatakan Abidin et al. (20I4) apabila terdapat gelembung udara, gelembung tersebut dapat menghalangi pandangan ketika melakukan pengamatan pada preparat. Adapun penyebab munculnya gelembung udara pada preparat dapat disebabkan oleh jaringan yang mengalami pengerutan akibat proses fiksasi yang tidak sempurna maupun gelembung udara pada saat penutupan dengan kaca penutup objek (Abidin et al., 2014; Ahmad et al., 2013).

\section{SIMPULAN}

Berdasarkan hasil penelitian maka dapat disimpulkan bahwa preparat histologi valid digunakan sebagai media pembelajaran pada submateri pencemaran air. Hasil validasi menunjukkan nilai rata-rata total validasi untuk preparat I.I sebesar 3,83; preparat I.2 sebesar 3,83; preparat 2.I sebesar 3,8I; preparat 2.2 sebesar 3,83; preparat 3.I sebesar 3,85; dan preparat 3.2 seebsar 3,85 .

\section{REFERENSI}

Abidin, A.Z., Budiono, J.D., \& Isnawati. (20I4). Studi indeks mitosis bawang untuk pembuatan media $\begin{array}{llll}\text { pembelajaran } & \text { mitosis. }\end{array}$ https://jurnalmahasiswa.unesa.ac.id/index.php/bioedu/article/view/9589

Ahmad, S.N.N., Budiono, J.D., \& Pratiwi, P.R. (2013). Pengembangan media preparat jaringan tumbuhan menggunakan pewarna alternatif dari filtrat daun pacar (lawsonia inermis). Bioedu, 2(I), 56-58. https://jurnalmahasiswa.unesa.ac.id/index.php/bioedu/article/view/I544

Baharuddin. (2015). Pengembangan media pembelajaran berbasis multimedia interaktif sekolah menengah kejuruan terhadap efektif dan efesiensi pembelajaran. Jurnal Inovasi dan Teknologi Pembelajaran, I(2), II5-I26. http://journal2.um.ac.id/index.php/jinotep/article/view/2II8/I253

Deadara, E., Suyanto, S., \& C Ciptono. (2017). Pengembangan media pembelajaran sistem reproduksi manusia berbasis android untuk meningkatkan pemahaman konsep peserta didik. Jurnal Prodi Pendidikan Biologi, 6(4), I98-2IO. http://journal.student.uny.ac.id/ojs/index.php/pbio/article/view/8104/77I I

Desriana, D., Amsal, A., \& Husita, D. (2018). Perbandingan Hasil belajar siswa menggunakan media pembelajaran berbasis lingkungan dengan media internet dalam pembelajaran asam basa di man indrapuri. Jurnal IPA dan Pembelajaran IPA, 2(I), 50-55. DOI: I0.248I5/jipi.v2iI.I0729

Enawaty, E., \& Sari, H. (2010). Pengaruh Penggunaan media komik terhadap hasil belajar siswa kelas x sma doli0.3I932/jpbio.v5iI.564 Panjaitan et al 
negeri 3 pontianak pada materi larutan elektrolit dan nonelektrolit. Jurnal Pendidikan Matematika dan IPA, I(I), 24-36. DOI: I0.264I8/jpmipa.vIiI.I63

Hanafy, M.S. (20I4). Konsep belajar dan pembelajaran. Lentera Pendidikan, I7/I), 66-79. http://journal.uinalauddin.ac.id/index.php/lentera_pendidikan/article/view/5I6

Heni, V., Duda, H.J., \& Supiandi, M.I. (20I7). Penerapan metode student facilitator and explaining berbantuan media peta timbul terhadap kemampuan berpikir kritis siswa pada materi sel. JPBIO (Jurnal Pendidikan Biologi), 2(2), 20-26. DOI: I0.31932/jpbio.v2i2.22I

Hestianah, E.P., Hidayat, N., \& Koesdarto, S. (2010). Pengaruh lama pemberian ekstrak rimpang temu ireng (curcuma aeruginosa roxb.) terhadap gambaran histopatologi hati mencit (mus musculus) jantan. Veterinaria Medika, 3(I), 4I-44. http://journal.unair.ac.id/download-fullpapers-Isi_8.pdf

Kiernan, J.A. (1990). Histological \& histochemical methods. Theory and practice, $2^{\text {nd }}$ edn. Pergamon Press. Canada.

Matsun, Darmawan, H., \& Fitriyanti, L. (2019). Pengembangan media pembelajaran fisika berbasis macromedia flash topik bahasan pesawat sederhana kelas viii smp. Jurnal Pendidikan Matematika dan IPA, IO(I), 3040. DOI: I0.264I8/jpmipa.vIOiI.2586I

Nurseto, T. (201 I). Membuat media pembelajaran yang menarik. Jurnal Ekonomi dan Pendidikan, 8(I), 19-35. DOI: I0.2183I/jep.v8iI.706

Panjaitan R.G.P., Manalu, W., Handharyni, E., \& Chairul. (2013). Hepatoprotective activity of eurycoma longifolia jack. roots. Indian Journal of Traditional Knowledge, I2(2), 225-230. http://nopr.niscair.res.in/bitstream/I23456789/I6865/I/IJTK\%20I2\%282\%29\%20225-230.pdf

Panjaitan, R.G.P., Savitri, E., \& Titin. (2016). Pengembangan media e-comic bilingual sub materi saluran dan kelenjar pencernaan. Unnes Science Education Journal, 5(3), 1379-I387. DOI: I0.I5294/usej.v5i3.13167

Panjaitan, R.G.P. (2017). Serum enzymes activity and liver histopathological changes of lactating mice treated with eurycoma longifolia jack. roots. Indian Jomal of Traditional Knowledge, I6(4), 593-597. http://nopr.niscair.res.in/bitstream/I23456789/42665/I/IJTK\%2016\%284\%29\%20593-597.pdf

Panjaitan, R.G.P., Lijana, \& Wahyuni, E.S. (2019a). The use of comic as a learning medium for ecology. Unnes Science Education Journal, 8(I), 4I-45. DOI: I0.I5294/usej.v8iI.23I94

Panjaitan, R.G.P., Wahyuni, E.S., \& Mega. (2019b). Film dokumenter sebagai media pembelajaran submateri zat aditif. JPBIO (Jurnal Pendidikan Biologi), 4(2), 52-59. DOI: I0.31932/jpbio.v4i2.454

Panjaitan, R.G.P., Titin, \& Santoso, R. (2019c). Film dokumenter pemanfaatan tumbuhan berkhasiat obat sebagai media pembelajaran pada materi sistem pencernaan. Jurnal Pendidikan Sains Indoenesia, 72), I2II3I. DOI: 10.24815/jpsi.v7i2.I4808

Paramita, R., Panjaitan, R.G.P., \& Ariyati, E. (2018). Pengembangan booklet hasil inventarisasi tumbuhan obat sebagai media pembelajaran pada materi manfaat keanekaragaman hayati. Jurnal IPA \& Pembelajaran IPA, 2(2), 83-88. DOI: 10.248I5/jipi.v2i2.I2389

Peraturan Pemerintah Nomor 82. (200I). Tentang pengelolaan kualitas air dan pengendalian pencemaran air, Jakarta. http://web.ipb.ac.id/ tml_atsp/test/PP\%20RI\%20NO_82_TAHUN_200I.pdf

Puspitasari, D.E. (2009). Dampak pencemaran air terhadap kesehatan lingkungan dalam perspektif hukum lingkungan (studi kasus Sungai Code di Kelurahan Wirogunan Kecamatan Mergangsan dan Kelurahan Prawirodirjan Kecamatan Gondomanan Yogyakarta). Mimbar Hukum, 2I(I), 23-34. DOI: I0.22I46/jmh.I6254

Pradilasari, L., Gani, A., \& Khaldun I. (2019). Pengembangan media pembelajaran berbasis audio visual pada materi koloid untuk meningkatkan motivasi dan hasil belajar siswa SMA. Jurnal Pendidikan Sains Indonesia, 7 I), 9-I5. DOI: I0.248I5/kanun.v\%25vi\%25i.I3293

Pramana, D.W., \& Dewi, N.R. (2014). Pengembangan e-Book IPA terpadu tema suhu dan pengukuran untuk menumbuhkan kemandirian belajar siswa, Unnes Science Education Journal, 3(3), 602-608. https://journal.unnes.ac.id/sju/index.php/usej/article/view/4266

Raehang. (20I4). Pembelajaran aktif sebagai induk pembelajaran kooperatif. Jurnal Al-Ta'dib, 7(I), I49-I67. http://ejournal.iainkendari.ac.id/al-tadib/issue/view/34/showToc

Riska, F., Syafruddin, D., \& Lisa, Y. (2018). Pengaruh metode guided note taking berbantuan media gambar terhadap hasil belajar siswa pada materi sistem peredaran darah pada manusia. JPBIO (Jurnal Pendidikan Biologi), 3(I), 26-32. DOI: 10.31932/jpbio.v3iI.263

Rozalinda, Albeta, S.W., Masnaini, \& Sulismawati. (2018). Pengaruh media prezi dan exe-learning terhadap hasil pembelajaran kimia. Jurnal Edusains, IO I), 65-73. DOI: I0.I5408/es.vIOiI.7204 
Setyosari, P. (2013). Metode penelitian pendidikan dan pengembangan. Jakarta: Kencana Prenadamedia Group.

Triadayani, A.E., Aryawaty, R., \& Diansyah, G. (2010). Pengaruh logam timbal (pb) terhadap jaringan hati ikan kerapu bebek (cromileptes altivelis). Maspari Journal, I, 42-47. DOI: I0.36706/maspari.vIiI.I078

Titin, Panjaitan, R.G.P., \& Yuliana, Y.G.S. (20I8). The development of character-based documentary film for the materials of reproduction system. Unnes Science Education Journal, 7(3), 25I-258. DOI: I0.I5294/usej.v7i3.23318

Umar. (2013). Media pendidikan: peran dan fungsinya dalam pembelajaran. Jurnal Tarbawiyah, IO(2), I26I4I. http://e-journal.metrouniv.ac.id/index.php/tarbawiyah/article/download/364/I77

Wahyuni, S., Emda, A., \& Zakiyah, H. (2018). Pengaruh penggunaan media animasi pada materi larutan elektrolit dan nonelektrolit terhadap kemampuan berpikir kritis siswa sma. Jurnal IPA dan Pembelajaran IPA, 2(I), 2I-28. DOI: I0.248I5/jipi.v2iI.I0743

Yamasari, Y. (2010). Pengembangan media pembelajaran matematika berbasis ict yang berkualitas. Seminar Nasional Pascasarjana, I-8.

Yendrita, \& Syafitri, Y. (2019). Pengaruh penggunaan media video pembelajaran terhadap hasil belajar biologi. Jurnal Pendidikan Biologi dan Sains, 2(I), 26-32. DOI: I0.3I539/bioedusains.v2iI.620

Zakia, A.R., Djamahar, D., \& Rusdi. (2019). Pengaruh pembelajaran berbasis masalah menggunakan media sosial e-learning terhadap hasil belajar siswa sekolah menengah pada sistem pencernaan. JPBIO (Jurnal Pendidikan Biologi), 4(I), 2I-28. DOI: I0.31932/jpbio.v4iI.395 